\title{
A REVIEW OF AFRICAN SWINE FEVER - DISEASE THAT IS NOW A BIG CONCERN IN EUROPE
}

\author{
Marina ŠTUKELJ ${ }^{1}$, Jan PLUT ${ }^{1 \bullet}$
}

\begin{abstract}
Summary: African swine fever (ASF) is a serious disease of domestic and feral swine mainly because of grave clinical course of the disease and its strong socio-economic impact. Not only there is an extremely high mortality (95-100\%) around the time of the first outbreak, live-animal, pork meat and other pork product trade is strongly affected on regional and international level. ASF is a species-specific disease; strength of the clinical signs depends on virulence of a viral strain. Exacerbation of body temperature and dysfunction of respiratory system and gastrointestinal tract are most common occurrences. Lesions can be mostly classed as congestive or hemorrhagic. Epidemiologically, ASF varies substantially among regions, countries and continents due to wide panel of different virus genotypes, population of feral swine and other reservoirs of disease, geographical characteristics and social habits of people. ASF is endemic in Sub-Saharan Africa where soft ticks (Argaside) and chronically infected feral swine population serve as reservoirs. It also became endemic in most parts of Russian Federation. Since 1978, ASF is endemic on Sardinia isle, as it was eradicated in all other parts of Europe. First outbreak in Georgia in 2007 has apparently served for transmission to other eastern European countries. Slovenia is currently still ASF-free but disease has already reached some relatively nearby countries (Poland, Romania, Moldova, Czech Republic and Hungary). There is no anti-ASF vaccine currently available ad specific treatment has not been described. Therefore rapid diagnostics and implementation of strict biosecurity measures play a key role in prevention of further transmission.
\end{abstract}

Key words: African swine fever, epidemiology, clinical signs, transmission, prevention.

\section{AFRICAN SWINE FEVER TRANSMISSION}

African swine fever has been known since 1909 when it was first discovered in Kenya (Montgomery, 1921). Disease spread quickly across Sub-Saharan Africa where it was exclusively present until 1957 (De Tray, 1957). Oversea pig market was the reason for transmission to Portugal and subsequently Spain and other European countries where isolated outbreaks have occurred since 1960; in the year of 1964 in France, years 1967, 1969 and 1983 in Italy, in 1985 in Belgium, in 1986 in the Netherlands and in 1987 in Malta. ASF cases were also confirmed across Atlantic; in 1971 and 1980 in Cuba, in 1978 in Dominican Republic and in 1979 in Haiti (Alvarez and Marcotegui, 1987). ASF was successfully eradicated everywhere but Sub-Saharan Africa and Sardinia isle where it is still endemic (Gallardo et al., 2015).

ASF outbreak was reported in 2007 in Georgia (Rowlands et al., 2007). It is suspected that disease was transmitted there from Southern parts of Africa. After that, disease spread to neighboring countries Azerbaijan and Armenia and over Caucasus mountains to Russian Federation. ASF became endemic in these countries and represents a constant threat for transmission to neighboring European countries (Gogin et al., 2013). The transmission indeed happened in 2013, to Belarus and Ukraine (Mur et al., 2016) and in 2014 to Latvia and Estonia (Oḷševskis et al., 2016). In 2014, virus spread from Belarus to Poland. ASF cases in these countries have been reported several times since then (Pejsak et al., 2014; Śmietanka et al. 2016; Woźniakowski et al. 2016), and in 2016, there was another outbreak in Ukraine, close to Romanian and Hungarian border (UVHVVR). In March 2017, an outbreak was reported in small backyard fattening farm in Moldova. The latest report on $27^{\text {th }}$ June 2017 has confirmed the first case of ASF in Czech Republic in the Zlín region, close to Slovakian and Austrian national borders. The virus was detected in wild boar. As seen from the map (Figure 1), the disease was transmitted undetected through long distance; either through large part of Poland or Slovakia (OIE.

\footnotetext{
${ }^{1}$ Marina Štukelj, PhD, Assistant Professor, Jan Plut, DVM, PhD student, Assistant, University of Ljubljana, Veterinary faculty, Clinic for Reproduction and Farm Animals, Clinic for Ruminants and Pigs, Gerbičeva 60, 1000 Ljubljana, Slovenia •Corresponding author: Jan Plut, Phone. +386 147792 02; E-mail: jan.plut@vf.uni-lj.si
} 
http://www.oie.int/wahis_2/public/wahid.php/Reviewreport/Review?page_refer=MapFullEventReport\&reportid=24 159).

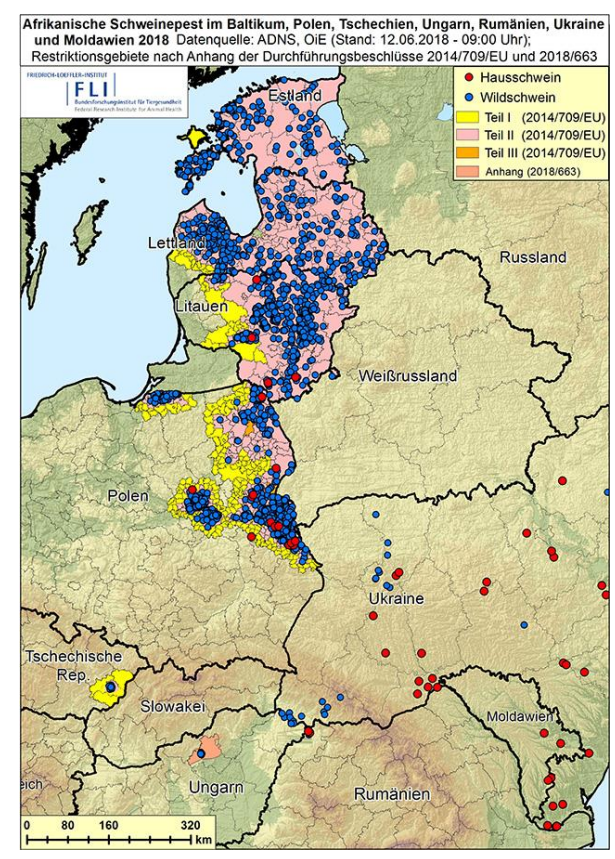

Figure 1: Latest geographical distribution of ASF in Eastern and Central Europe (Source: Friedrich Loeffler Institut; https://www.fli.de/de/aktuelles/tierseuchengeschehen/afrikanische-schweinepest/karten-zur-afrikanischen-schweinepest/).

Since 2007, ASF spread from Georgia to Russia and then to Baltic countries in the north and Belarus, Poland and Ukraine to the west. The Latest case of ASF was confirmed on $23^{\text {th }}$ of April 2018 in Hungary (Source: adapted from OIE report).

\section{ETIOLOGY}

ASF is caused by DNA virus from Asfaviridae family (Dixon et al., 2005). Twenty-two distinct ASF virus (ASFv) genotypes (I-XXII) were recorded and are in circulation in Africa (Figure 2). Only genotype I outbreaks were noted in Europe and America until 2007 Georgia outbreak when genotype II (Gallardo et al., 2014) from East Africa was confirmed (Figure 2). Only one genetic variant is currently spreading in Eastern Europe, although there are some genetic differences between closely related strains and that option should be additionally explored in the future. Spreading of ASF is slow, but is constantly progressing (Dixon et al., 2013). 


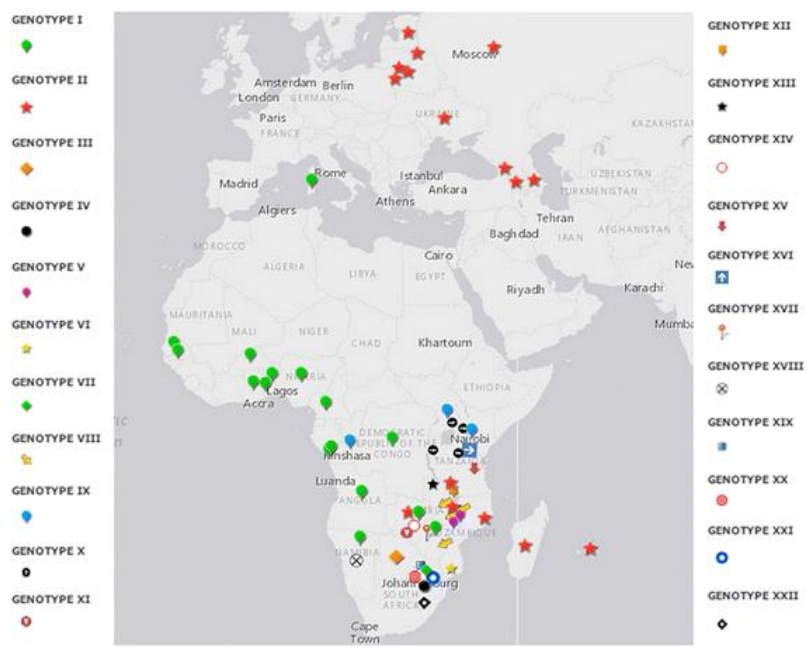

Figure 2: Distribution of different ASFv genotypes in Europe in Africa, Europe and Caucasus region (Gallardo, 2009; Gallardo et al., 2015).

Until year 2007, most of the European ASF cases belonged to genotype 1. After that year, all outbreaks in the Eastern Europe were determined genotype 2 (Gallardo, 2009; Gallardo et al., 2015).

ASFv strains with different virulence can be distinguished into highly virulent strains (90-100\% mortality), moderately virulent strains (70-80\% mortality in young animals and 20-40\% mortality in adults) and low virulent strains with 10-30\% mortality (Blome et al., 2013)

\section{EPIDEMIOLOGY}

Common reservoirs of ASFv are soft ticks from Argasidae family, Ornithodoros spp. that mostly appear in Africa but also in some Mediterranean countries and Middle East including Transcaucasia (Costard et al., 2013). Both domestic pigs and European wild boars are equally susceptible to ASFv infection. In contrast, in African wild suid species infection is usually inapparent with low ASFv loads in blood, thus they can transmit the disease for several years (Jori and Bastos, 2009). ASFv is transmitted with infected domestic pigs, infected wild boars, humans with their activity in swine herds, transportation vehicles that transported infected pigs, pork and other meat products containing pork and infected soft ticks (Sánchez-Vizcaíno and Arias Neira, 2012).

Infective animals shed ASFv in all secretions and excretions. Route of transmission is usually direct oro-nasal contact or indirect through contact with infected equipment, bedding material, dead pigs or semen. Outdoor domestic swine can come in contact with feral swine population (Penrith and Vosloo, 2009; Guinat et al., 2014).

Global marketing with pigs, pork and meat products is very intense. Entry point for disease are usually purchase of infected animals, therefore purchase of certified negative pigs from ASF free countries is of most high importance. Import of pigs and pork products from ASF positive countries is illegal (Mur et al., 2012; Gallardo et al., 2015).

$\mathrm{ASFv}$ is very stable in meat and meat products especially at lower temperatures where it can stay infective for more than a year. Important route of transmission is swill feeding which is also illegal in EU (Farez and Morley, 1997; Beltrán-Alcrudo et al., 2008; Sánchez-Vizcaíno and Arias Neira, 2012).

Slovenia is a high transit country. Not only vehicles but also drivers can serve as potential vectors through direct skin contact, contact with contaminated clothes and equipment or meat products.

\section{INFECTION AND PATHOGENESIS}

Pigs usually become infected through oro-nasal contact with ASFv of from tick bites (Costard et al., 2013). Incubation period lasts 3-19 days (Bech-Nielsen et al., 1995; Gogin et al., 2013). In peracute (sudden death with no or few clinical signs) (Montgomery, 1921; Vinuela, 1985.) and acute cases ASFv replicates monocytes and macrophages in lymphatic tissue (lymph nodes) in 24 hours and spreads into the bloodstream (viremic phase) (De Tray, 1957; Boinas et al., 2004). Virus can also replicate in hepatocytes, endothelial cells, renal tubular epithelial cells and neutrophils (Rojo et al, 1999; Dixon et al., 2013) - replication impairs the integrity of circulatory system and causes leucopenia - which results in thrombocytopenia and immunosuppression (Arias et al, 2002; SanchezCordon et al., 2005). In acute ASF, severe disseminated intravascular coagulopathy (DIC) with formation of platelets and plugs can appear from 3-5 days post infection onward (Villeda et al., 1993), which may be followed by 
thrombocytopenia in the final stage of acute phase because of inability of bone marrow to compensate for DIC (Anderson et al., 1987). Impaired blood stream permeability can cause death from pulmonary edema in 4-5 days after infection (Gómez-Villamandos et al., 1997). Viral shedding can start 24 hours after infection but more commonly 7-10 days after onset of pyrexia (Figure 3). Viremia usually lasts for 8 weeks, ASF is present in lymphatic tissue for 12 weeks, in some cases 21 weeks or more (Hamdy and Dardiri, 1984).

Mortality is usually not $100 \%$. Survivors usually become a source of infection for other animals for a limited amount of time; results from other authors show that the time span of virus shedding of surviving pigs can vary, some of the studies report that there are no signs of long-term persistence of ASFv in a latent state (Penrith and Vosloo, 2009; EFSA 2010; Guinat et al., 2014); results of these studies are especially consistent for European epidemiologic situation where European wild boar (Sus scrofa) and feral pigs are very susceptible to the disease and show similarly high lethality as domestic pigs (Gallardo et al., 2015). On the contrary, wild African Suidae develop persistent infections and act like virus reservoirs (Penrith and Vosloo, 2009). Authors do report about formation of two endemic zones in central and southern Russia, which might point towards existence of persistently infected animals in European region (Gogin et al., 2013); that is also the case on the isle of Sardinia where ASF has been present since 1978. Anti-ASFv antibodies are detected but do not neutralize the virus. Glomerulonephritis is a common pathological finding in these animals (Penrith and Vosloo, 2009).

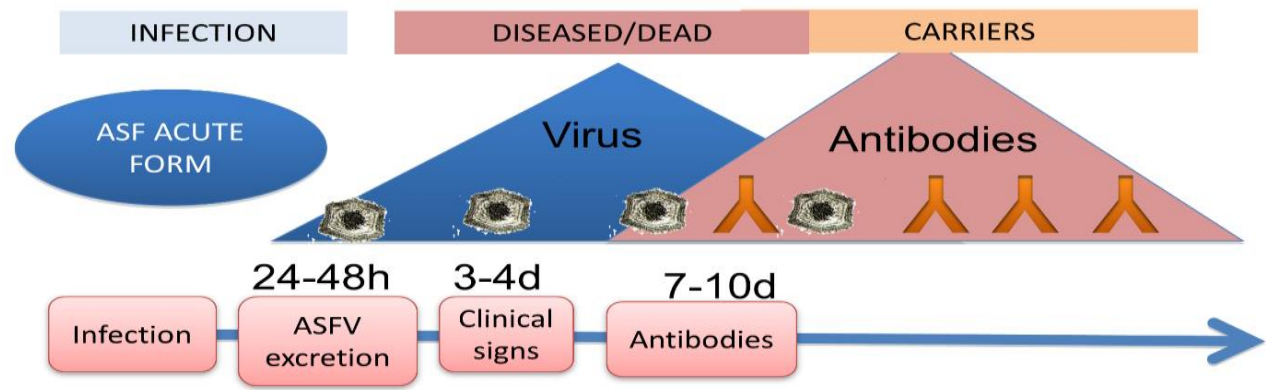

Figure 3: Pathogenesis of ASF (Gómez-Villamandos et al., 1997).ASF replicates in monocytes and macrophages closest to the virus entry point. ASFv spreads via blood or lymph. Viremia appears 2-3 days or 8 days after infection (Sánchez-Vizcaíno and Arias Neira, 2012). Virus persists in the host due to lack of neutralization antibodies. Secondary replication can take place in lymph nodes, bone marrow, spleen, kidneys, lungs and liver (Gómez-Villamandos et al., 1997).

\section{STABILITY OF ASFV}

ASF is very stable and can remain infective in pig carcasses for months, particular at low temperatures (6 months at $4^{\circ} \mathrm{C}$ ). In frozen meat, it can remain infective for years. It can be isolated from blood or serum after 18 months stored at room temperature. Viability in uncleaned pig pens is estimated at 1 month (Farez and Morley, 1997; Beltrán-Alcrudo et al., 2008; Sánchez-Vizcaíno and Arias Neira, 2012).

ASF is sensitive to high temperatures - inactivation in $2 \mathrm{~h}$ at $56^{\circ} \mathrm{C}$ or in $20 \mathrm{~min}$ at $70^{\circ} \mathrm{C}$. Virus is stable in $3-10$ $\mathrm{pH}$ range. Use of $1 \%$ formaldehyde or $2 \% \mathrm{NaOH}$ inactivates it in 6 days and 24 hours respectively (Plowright and Parker, 1967; Edwards, 2000; EFSA 2010).

\section{CLINICAL SIGNS}

Clinical manifestation is in correlation with ASFv virulence. Highly virulent strains cause peracute or acute infections, moderately virulent strains cause acute or subacute infections and low virulent strains subacute of chronic infections. In peracute form, elevated body temperature $\left(41-42^{\circ} \mathrm{C}\right)$, loss of appetite, apathy, rapid, labored breathing, exanthemas and cyanotic foci and death in 1-4 days usually occur (Gallardo et al., 2015). In acute form elevated body temperature around $40^{\circ} \mathrm{C}$, loss of appetite, apathy, labored breathing, nasal discharge, exanthemas and hematomas (ears, tail, lower extremities, skin hemorrhages, cyanotic mucosa) (Figure 4 and Figure 5), uncoordinated movement, huddling, bloody diarrhea, abortions and 90-100\% mortality in first 7 days can be observed (Blome et al., 2013). 


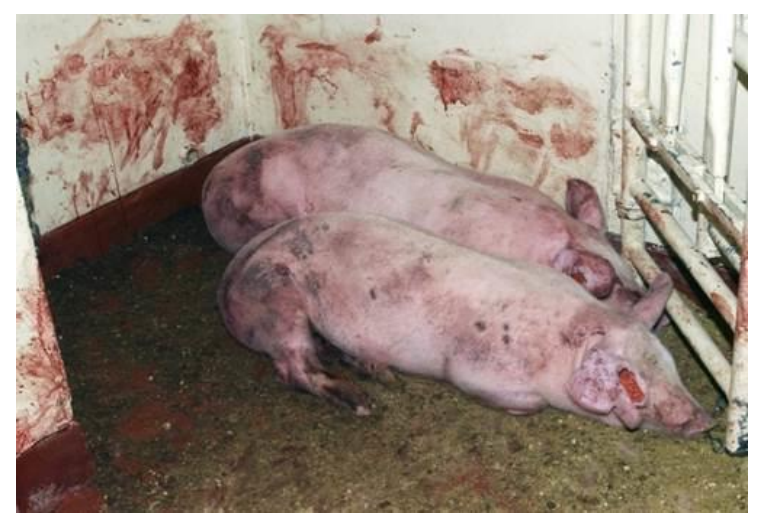

Figure 4: Severe hemorrhages (http://asforce.org/course/)

Severe hemorrhages as the cause of trombocytopenia; blood can be seen on the floor, walls and hind legs of two fatteners (http://asforce.org/course/)

Chronic form is manifested with higher rate of secondary bacterial infections, hemorrhagic purpura of ears, abdomen with tendency to spread across the skin, ulcerate or necrotize, slightly elevated body temperature, respiratory disorders, leg pain (arthritis) and low mortality rates (Sánchez-Vizcaíno et al., 2015).

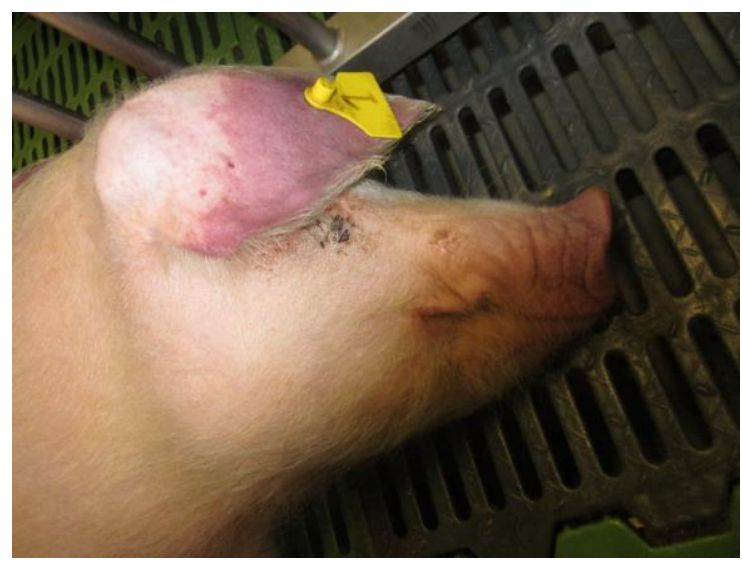

Figure 5: Cyanotic ears (http://asforce.org/course/)

Various extremities may be cyanotic due to changed bloodstram permeability and lack of blood oxygenation (http://asforce.org/course/)

\section{PATHOLOGICAL FINDINGS}

Pathological lesions may be absent in peracute form. In other forms of ASF hemorrhagic syndrome, hemorrhagic splenomegaly, lymph node hemorrhages (usually in gastric and renal area), petechial hemorrhages of kidneys, urinary bladder, pharynx and larynx mucosa and hearth can be observed. Pulmonary and gall bladder edema can also be present (Dahle and Liess, 1992; Gómez-Villamandos et al., 1995; Sánchez-Vizcaíno et al., 2015).

\section{LABORATORY DIAGNOSTICS}

Anamnesis, clinical signs and pathological findings serve as bases for assumptive diagnosis. ASF can then be confirmed with different laboratory diagnostic tests. Appropriate samples for laboratory testing are whole blood, serum and various tissue samples (spleen, liver, lungs, tonsils, kidneys, mediastinal and retropharyngeal lymph nodes). For antigen detection real-time PCR (qPCR), hemadsorption test, ASFv isolation on macrophages and sandwich ELISA can be used. Anti-ASF antibodies can be detected with indirect ELISA or immunoblotting tests (Oura and Arias, 2008; Sánchez-Vizcaíno and Arias Neira, 2012). 


\section{DIFFERENTIAL DIAGNOSIS}

Classical swine fever (CSF) is clinically indistinguishable and must be confirmed with laboratory testing. Other diseases like postweaning multisystemic wasting syndrome (PMWS)/porcine dermatitis and nephropathy syndrome (PDNS), acute, highly virulent PRRS, erysipelas, salmonellosis, Aujeszky's disease, eperythrozoonosis, pasteurellosis and heavy metal poisoning can be considered for differential diagnosis (Sánchez-Vizcaíno and Arias Neira, 2012).

\section{ASF MEASURES TO BE APPLIED IN CASE OF OUTBREAK AND ACTS OF LEGISLATION}

ASF is disease legislated in Slovenian Regulation act of animal diseases (Official Journal of the Republic of Slovenia, no. 81/07 and 24/10). ASF outbreak must be reported to competent national and international authorities. National regulations must be prepared and implemented in case of disease outbreaks. Vaccination against ASF is prohibited by Supplement 3 of Official Journal of the Republic of Slovenia, no. 81/07. All costs of disease are covered from national budget. National plan for ASF measures and Regulation act for detection, prevention and eradication of ASF were prepared by Ministry of agriculture, forestry and food and the Administration of the Republic of Slovenia for food safety, veterinary and plant protection.

Apart from national legislation, there is also European Council directive 2002/60/ES of the $27^{\text {th }}$ of June 2002 laid down minimal measures implemented in EU for monitoring of ASF in domestic and feral swine. Commission implementing decision 2014/709/EU of 9 October 2014 defines control measures relating to African swine fever in certain Member States. The newest is Commission Implementing Decision (EU) 2017/351 amending the Annex to Implementing Decision 2014/709/EU concerning animal health control measures relating to African swine fever in certain Member States. Commission Decision 2003/422/EC of 26 May 2003 approved an African swine fever diagnostic manual.

EC is preparing a strategy SANTE/7113/2015 - rev 4 for Eastern Europe to prevent ASF transmission across EU. Also working document SANCO/7138/2013 is prepared for monitoring and implementation of preventive measures for domestic pigs and wild boars. Working document SANTE/7112/2015 provides principles and criteria for geographically defining ASF regionalization.

\section{MEASURES FOR PREVENTION OF ASF TRANSMISSION}

Since 2014, $1 \%$ of dead domestic and wild pigs in Slovenia is screened for ASF as part of protocol written in the Order on the systematic monitoring of animal health status, disease eradication programs and vaccination in 2016 (Official Journal of the Republic of Slovenia, no. 105/15, 4/16 and 56/16).

Measures against ASF are complex and very expensive. There is no effective vaccine currently available (Escribano et al., 2013). Therefore avoiding disease entry to the farm is the most important form of protection. That can be achieved only with EU Directive completely synchronized between all EU member states and with carefully prepared action plan in case of ASF outbreak, with sufficient number of diagnostic facilities available to provide rapid diagnosis and prevent further transmission from infected area.

Implementation of strict biosecurity measures that ensure prevention of disease introduction and provide biocontainment in case of an outbreak is necessary. All purchased pigs must be free of ASF and other important diseases and accompanied with formal health status certificate. Pigs should not be bought from ASF positive countries. A month long isolation in quarantine should be applied for all newly bought pigs. Samples should be taken and tested for diseases during that period. Blood should be drawn twice for ASF testing; 24-48 hours after arrival and right before the end of the isolation period. Semen for artificial insemination should be purchased from healthy boars from official breeding companies and accompanied health status certificate as well. Swill feeding should be strictly prohibited as ASFv can transmit with pork and other meat products. Vehicles for animal transport should be cleaned, disinfected and dried up prior to transport. Trucks should not enter the farm grounds; loading and unloading docks for animals should be located outside the fence surrounding the farm.

Number of farm visitors should be limited to as few as possible. Visitors should be provided with clean clothes and footwear kept exclusively on the farm. The same goes for all animal handling equipment unless disinfected or sterilized before entering.

Contact of domestic and feral swine should be prevented for wild boars can be disease carriers. Wild boar population should be monitored and dead bodies should be removed quickly and in a safe manner. Fast and sufficient diagnostic procedures are key in prevention of ASF transmission. All animal movements should be registered and monitored at all times. People who work with domestic or wild pigs and people in pork production chain should be informed and educated about ASF and measures against the disease (Bellini et al., 2016). 


\section{CONCLUSION}

Vehicles from Baltic countries and Poland enter Slovenia daily. Pigs are usually not imported from these areas but illegal pork and meat product imports and unsanitary vehicles could be risk factors for disease introduction for domestic and wild pigs. Feral swine population is increasing globally and in Slovenia. Outdoor-bred pigs and pigs with any access to the outside of farm facilities could come in contact with wild pig population. Thus, any domestic and wild pig contact should be averted at all times, and population of feral swine should be strictly monitored and dead wild boars should be continuously removed. Backyards and free-range domestic pig represent the weakest link in the biosecurity chain and the biggest risk factor for ASF introduction. Strict and precise biosecurity measures are necessary for good health status of our animals. Swill feeding should be prohibited to limit transmission with pork and other meat products.

Europe is aware of negative effects of introduction and transmission of ASF. Many international programs were prepared for preventing this scenario. One of these programs is also COST (European Cooperation in Science and Technology) action "Understanding and combating African swine fever in Europe" (ASF-STOP, Cost Action CA15116) whose active member is also Slovenia.

\section{REFERENCES}

ALVAREZ, A.O., MARCOTEGUI, M.A.: African swine fever - clinical aspects. In: African Swine Fever. (Y. Becker, ed.), Developments in Veterinary Virology, Vol. 3, Springer, Boston, pp.11-20,1987.

ANDERSON, E.C., WILLIAMS, S.M., FISCHER-HOCH, S.P., WILKINSON, P.J.: Arachidonic acid metabolites in the pathophysiology of thrombocytopenia and haemorrhage in acute African swine fever. Res. Vet. Sci., 42:387-394, 1987.

ARIAS, M., SÁNCHEZ-VIZCAÍNO, J.M., MORILLA, A., YOON, K.J., ZIMMERMAN, J.J.: African swine fever. In: Trends in emerging viral infections of swine (A. Morilla, K.J. Yoon, J.J. Zimmerman, eds.). Iowa State Press, Ames, pp.119-124,2002. BECH-NIELSEN, S., FERNANDEZ, J., MARTINEZ-PEREDA, F., ESPINOSA, J., BONILLA, Q.P., SÁNCHEZ-VIZCAÍNO, J.M.: A case study of an outbreak of African swine fever in Spain. Br. Vet. J., 151(2)203-214,1995.

BELLINI, S., RUTILE, D., GUBERTI, V.: Preventive measures aimed at minimizing the risk of African swine fever virus spread in pig farming systems. Acta Vet. Scand., 58:82,2016.

doi: 10.1186/s13028-016-0264-X.

BELTRÁN-ALCRUDO, D., LUBROTH, J., DEPNER, K., DE LA ROCQUE, S.: African swine fever in the Caucasus. FAO

Empres Watch, 1-8,2008.

BLOME, S., GABRIEL, S., BEER, M.: Pathogenesis of African swine fever in domestic pigs and European wild boar. Virus

Res., 173:122-130,2013.

doi: 10.1016/j.virusres.2012.10.026.

BOINAS, F.S., HUTCHINGS, G.H., DIXON, G.H., WILKINSON, P.J.: Characterization of pathogenic and non-pathogenic African swine fever virus isolates from Ornithodoros erraticus inhabiting pig premises in Portugal. J. Gen. Virol.,

85(8)2177-2187,2004.

COSTARD, S., MUR, L., LUBROTH, J., SÁNCHEZ-VIZCAÍNO, J.M., PFEIFFER, D.U.: Epidemiology of African swine fever virus. Virus Res., 173(1)191-197,2013.

doi: org/10.1016/j.virusres.2012.10.030.

DAHLE, J., LIESS, B.: A review on classical swine fever infections in pigs: epizootiology, clinical disease and pathology. Comp. Immunol. Microbiol. Infect. Dis., 15(3)203-211, 1992.

DE TRAY, D.E.: African swine fever in warthogs (Phacochoerus aethiopicus). J. Am. Vet. Med Assoc., 130:537-540,1957.

DIXON, L.K., ESCRIBARO, J.M., MARTINS, C., ROCK, D.L., SALAS, M.L., WILKINSON, P.J.: Asfaviridae. In: Virus

Taxonomy (C.M. Fauquet, M.A. Mayo, J. Maniloff, U. Desselberger, L.A. Ball, eds.), Eighth Report of the International

Committee on Taxonomy of Viruses ICTV, Elsevier/Academic Press, London, UK, pp.135-43, 2005.

DIXON, L.K., CHAPMAN, D.A.G., NETHERTON, C.L., UPTON, C.: African swine fever replication and genomics. Virus Res., 173(1)3-14,2013.

doi: 10.1016/j.virusres.2012.10.020.

EDWARDS, S.: Survival and inactivation of classical swine fever virus. Vet. Microbiol., 73(2)175-181,2000.

EUROPEAN FOOD SAFETY AUTHORITY (EFSA): EFSA panel on animal health and welfare: Scientific opinion on African swine fever. EFSA J., 8(3)1556,2010.

doi: 10.2903/j.efsa.2010.1556.

ESCRIBANO, J.M., GALINDO, I., ALONSO, C.: Antibody-mediated neutralization of African swine fever virus: myths and facts. Virus Res., 173(1)110-121,2013.

doi: 10.1016/j.virusres.2012.10.012.

FAREZ, S., MORLEY, R.S.: Potential animal health hazards of pork and pork products. Rev. Sci. Tech. Off. Int. Epiz., 16:65-78,1997.

doi: 10.20506/rst.16.1.992. 
GALlARDO, C., DE LA TORRE REOYO, A., FERNÁNDEZ-PINERO, J., IGLESIAS, I., MUÑOZ, J., ARIAS, L.: African swine fever: a global view of the current challenge. Porcine Health Manag., 21:1,2015.

doi: 10.1186/s40813-015-0013-y.

GALLARDO, C., FERNÁNDEZ-PINERO, J., PELAYO, V., GAZAEV, I., MARKOWSKA-DANIEL, I., PRIDOTKAS, G., NIETO, R., FERNÁNDEZ-PACHECO, P., BOKHAN, S., NEVOLKO, O., DROZHZHE, Z.: Genetic variation among African swine fever genotype II viruses, eastern and central Europe. Emerg. Infect. Dis., 20(9)1544,2014.

doi: 10.3201/eid2009.140554

GOGIN, A., GERMANISOV, V., MALOGOLOVKIN, A., KOLBASOV, D.: African swine fever in the North Caucasus region and the Russian Federation in years 2007-2012. Virus Res., 173:198-203,2013.

doi: 10.1016/j.virusres.2012.12.007.

GÓMEZ-VILlAMANDOS, J. C., BAUTISTA, M.J., CARRASCO, L., CABALlERO, M.J., HERVÁS, J., VILLEDA, C.J., WILKINSON, P.J., SIERRA, M.A.: African swine fever virus infection of bone marrow: lesions and pathogenesis. Vet. Pathol., 34:97-107,1997.

GUINAT, C., REIS, A.L., NETHERTON, C.L., GOATLEY, L., PFEIFFER, D.U., DIXON, L.: Dynamics of African swine fever virus shedding and excretion in domestic pigs infected by intramuscular inoculation and contact transmission. Vet. Res.,

45:93,2014.

doi: 10.1186/s13567-014-0093-8.

HAMDY, F.M., DARDIRI, A.H.: Clinical and immunologic responses of pigs to African swine fever virus isolated from the Western Hemisphere. Am. J. Vet. Res., 45(4)711-714,1984.

JORI, F., BASTOS, A.D.: Role of wild suids in the epidemiology of African swine fever. Ecohealth., 6(2)296-310,2009.

MONTGOMERY R.E.: A form of swine fever occurring in British East Africa (Kenya colony). J. Comp. Pathol.,

34:159-191,1921.

MUR, L., IGOLKIN, A., VARENTSOVA, A., PERSHIN, A., REMYGA, S., SHEVCHENKO, I., ZHUKOV, I., SÁNCHEZ-

VIZCAÍNO, J.M.: Detection of African swine fever antibodies in experimental and field samples from the Russian Federation: implications for control. Transbound. Emerg. Dis., 63:436-440,2016.

doi:10.1111/tbed.12304.

MUR, L., MARTÍNEZ-LÓPEZ, B., MARTÍNEZ-AVILÉS, M., COSTARD, S., WIELAND, B., PFEIFFER, D.U., SÁNCHEZVIZCAÍNO, J.M.: Quantitative risk assessment for the introduction of African swine fever virus into the European Union by legal import of live pigs. Transbound. Emerg. Dis., 59(2)134-144,2012.

doi: 10.1111/j.1865-1682.2011.01253.x.

OĽŠEVSKIS, E., GUBERTI, V., SERŽANTS, M., WESTERGAARD, J., GALLARDO, C., RODZE, I., DEPNER, K.: African swine fever virus introduction into the EU in 2014: experience of Latvia. Res. Vet. Sci., 105:28-30,2016.

doi: 10.1016/j.rvsc.2016.01.006.

OULA, C.A.L., ARIAS, M.: 2.8.1. African swine fever. In: Manual of Diagnostic Tests and Vaccines for Terrestrial Animals (OIE). Paris, World organization for animal health, pp.1069-82,2008.

PEJSAK, Z., TRUSZCZYŃSKI, M., NIEMCZUK, K., KOZAK, E., MARKOWSKA-DANIEL, I.: Epidemiology of African swine fever in Poland since the detection of the first case. Pol. J. Vet. Sci., 17(4)665-672,2014.

PENRITH, M. L., VOSLOO, W.: Review of African swine fever: transmission, spread and control. J. S. Afr. Vet. Assoc., 80:58-62,2009.

PLOWRIGHT, W., PARKER, J.: The stability of African swine fever virus with particular reference to heat and $\mathrm{pH}$ inactivation. Arch. Virol., 21(3)383-402,1967.

ROJO, G., GARCÍA-BEATO, R., VIÑUELA, E., SALAS, M.L., SALAS, J.: Replication of African swine fever virus DNA in infected cells. Virology, 257(2)524-536,1999.

ROWLANDS, R. J., MICHAUD, V., HEATH, L., HUTCHINGS, G., OURA, C., VOSLOO, W., DWARKA, R., ONASHVILI, T., ALBINA, E., DIXON, L.K.: African swine fever virus isolate, Georgia, 2007. Emerg. Infect. Dis., 14(12)1870-1874,2008. doi: 10.3201/eid1412.080591.

SANCHEZ-CORDON, P.J., NUNEZ, A., SALGUERO, F.J., PEDRERA, M., DE MARCO, M.F., GOMEZ-VILLAMANDOS, J.C.: Lymphocyte apoptosis and thrombocytopenia in spleen during classical swine fever: role of macrophages and cytokines. Vet. Pathol., 42(4)477-488,2005.

SÁNCHEZ-VIZCAÍNO, J. M., ARIAS NEIRA, M.: African swine fever virus. In: Diseases of Swine (J.J. Zimmerman, L.A. Karriker, A. Ramirez, K.J. Schwartz, G.W. Stevenson, eds.), Iowa State Press, Ames, Iowa, pp. 501-24,2012.

SÁNCHEZ-VIZCAÍNO, J.M., MUR, L., GOMEZ-VILLAMANDOS, J.C., CARRASCO, L.: An update on the epidemiology and pathology of African swine fever. J. Comp. Pathol., 152(1)9-21,2015.

doi: 10.1016/j.jcpa.2014.09.003.

ŚMIETANKA, K., WOŹNIAKOWSKI, G., KOZAK, E., NIEMCZUK, K., FRĄCZYK, M., BOCIAN, Ł., KOWALCZYK, A., PEJSAK, Z.: African swine fever epidemic, Poland, 2014-2015. Emerg. Infect. Dis., 22(7)1201-1217,2016.

doi: 10.3201/eid2207.151708.

VINUELA, E.: African swine fever virus. Curr. Top. Microbiol. Immunol., 116:151-170,1985.

VILLEDA, C.J., WILLIAMS, S.M., WILKINSON, P.J., VIÑUELA, E.: Consumption coagulopathy associated with shock in acute African swine fever. Arch. Virol., 133:467-475,1993.

WOŹNIAKOWSKI, G., KOZAK, E., KOWALCZYK, A., ŁYJAK, M., POMORSKA-MÓL, M., NIEMCZUK, K., PEJSAK, Z.: Current status of African swine fever virus in a population of wild boar in eastern Poland (2014-2015). Arch. Virol.,

161:189-195,2016. 


\title{
AFRIČKA KUGA SVINJA - BOLEST KOJA SE VEĆ ŠIRI PO EVROPI
}

\author{
Marina ŠTUKELJ, Jan PLUT
}

Izvod: Afrička kuga svinja (AKS) je vrlo opasna virusna bolest svinja, posebno zbog velikih zdravstvenih i društveno-ekonomskih posledica. Na početku bolesti, javlja se ne samo veliki procenat uginulih svinja (95 - 100\%), već je pogođena i trgovina svinja, svinjskog mesa i mesnih proizvoda na regionalnoj i međunarodnoj osnovi. Bolest je vrlo specifična i zavisno od virulencije soja virusa uzrokuje razvoj raznih kliničkih znakova bolesti. Najtipičnije su porast telesne temperature, te funkcionalni poremećaj probavnog i disajnog sistema. Većina promena može biti okarakterisana kao kongestivno-hemoragična promena. Epidemiološki se AKS mnogo razlikuje od zemlje do zemlje, regija i kontinenata zbog pojave različitih genotipova virusa u pojedinačnim zemljama, zbog različite veličine populacije divljih svinja, zbog prisutnosti raznih rezervoara virusa, zbog različitih uslova okoline i zbog različitog socijalnog ponašanja ljudi. Trenutno, AKS je endemska u većini zemlja supsaharske Afrike, glavni vektori prenosa su virusa krpelji i divlje svinje koje su hronično zaražene. Bolest je takođe endemsko prisutna u većini zemalja Ruske Federacije. U Evropi bolest je već endemski prisutna od 1978 godine na Sardiniji, u drugim pogođenim zemljama Evrope bolest su eradicirali. Od 2007 godine kada je bolest prvi put potvrđena u Gruziji, proširila se i na ostale zemlje istočne Evrope. Slovenija je bez AKS ali se bolest brzo širi i sada je već u severoistočnoj Evropi (Poljska, Baltičke države, Moldavija). Trenutno na tržištu još uvek nema efikasne vakcine protiv AKS i takođe ne postoji specifičan tretman, tako da je veoma bitno sprečiti širenje bolesti i što brze uspostavljanje dijagnoze bolesti te uvođenje strogih bio-sigurnosnih mera.

Ključne reči: Afrička svinjska kuga, epidemiologija, klinička slika, prevencija, kontrola

\section{Received / Primljen: 14.09.2017. Accepted / Prihvaćen: 07.05.2018.}

